6. Проект Національної транспортної стратегії України на період до 2030 року [Електронний ресурс] Режим доступу: https://mtu.gov.ua/projects/115/

7. Шуплат О.М. Фінансове забезпечення інвестиційної діяльності підприємств сфери туризму / О.М. Шуплат // Дисертація на здобуття наукового ступеня кандидата економічних наук, 08.00.08 - Гроші, фінанси і кредит . - 2016, Київ. - 302 с.

8. Чернікова В. I. Особливості інновацій у туризмі. [Електронний ресурс] / В. І. Чернікова // Вісн. ДІТБ. - № 16. C.89-94. Режим доступу:http://tourlib.net/statti_ukr/cherniko va.htm

DOI 10.18664/338.47:338.45.v\%vi\%i.134046
9. Прохорова В.В. Формування системи управлінських інновацій як передумова інноваційного розвитку підприємств / В.В. Прохорова // Науковий журнал: Економіка i управління. Національна Академія природоохоронного та курортного будівництва. - 2012. - №3. - С. 68-73.

10. Прохорова В.В., Давидова О.Ю. Методологія процесу формування інноваційного управління розвитком підприємств/ Прохорова В.В., О.Ю. Давидова // Научный информационный Журнал «Бизнес Информ», № 12`2017. C. 210-214.

УДК 338. 47: 656. 2

\title{
ВПЛИВ СУЧАСНИХ ФАКТОРІВ КАДРОВОЇ СКЛАДОВОЇ НА ЗАБЕЗПЕЧЕННЯ ЕКОНОМІЧНОЇ БЕЗПЕКИ ЗАЛІЗНИЧНОГО ТРАНСПОРТУ
}

\author{
Тимофеєва Т.О., к.е.н., доцент (УкрДУЗТ)
}

Сформовано комплексний підхід до формування механізму забезпечення кадрової складової економічної безпеки залізничного транспорту. Виявлено вплив сучасних факторів впливу кадрової складової на забезпечення економічної безпеки залізничного транспорту. Приведено схему загроз кадрової складової економічної безпеки залізничного транспорту. Встановлено, що система економічної безпеки залізничного транспорту повинна формуватися 3 урахуванням сучасних сочіальних змін в суспільстві. Виявлено напрямки, які орієнтовані, на забезпечення кадрової складової економічної безпеки залізничного транспорту. Встановлено перелік основних завдань по вдосконалення кадрової безпеки залізничного транспорту.

Ключеві слова: управління персоналом, економічна безпека залізничного транспорту, кадрова складова, управління виробництвом, організаційна структура. 


\title{
ВЛИЯНИЕ СОВРЕМЕННЫХ ФАКТОРОВ КАДРОВОЙ СОСТАВЛЯЮЩЕЙ НА ОБЕСПЕЧЕНИЕ ЭКОНОМИЧЕСКОЙ БЕЗОПАСНОСТИ ЖЕЛЕЗНОДОРОЖНОГО ТРАНСПОРТА
}

\author{
Тимофеева T.Е, к.е.н., доцент (УкрГУЖТ)
}

Сформирован комплексный подход до формирования механизма обеспечения кадровой составляющей экономической безопасности железнодорожного транспорта. Выявлено влияние современных факторов влияния кадровой составляющей на обеспечение экономической безопасности железнодорожного транспорта. Приведена схема угроз кадровой составляющей экономической безопасности железнодорожного транспорта. Установлено, что система экономической безопасности железнодорожного транспорта должна формироваться с учетом современных сочиальных изменений в обществе. Выявлены направления, которые ориентированы на обеспечение кадровой составляющей экономической безопасности железнодорожного транспорта. Установлен перечень основных заданий по совершенствованию кадровой безопасности железнодорожного транспорта.

Ключевые слова: управление персоналом, экономическая безопасность жселезнодорожного транспорта, кадровая составляющая, управление производством, организационная структура.

\section{INFLUENCE OF MODERN FACTORS OF THE PERSONNEL COMPONENT TO ENSURING ECONOMIC SAFETY OF RAILWAY TRANSPORT}

\section{Timofeeva T.E., Candidate of Economic Sciences, associate professor (USURT)}

One of issues of the day on the modern stage of development of economy of country from positions of economic security there is direction of management a personnel. This direction of providing of economic security is included in one of her constituents - skilled constituent. Therefore in the article complex approach is formed to forming of mechanism of providing of skilled constituent of economic security of railway transport, where main yaza is spared to direction of management a personnel. Influence of modern factors of influence of skilled constituent is educed on providing of economic security of railway transport. These factors are conditioned by modern social changes in society, such as democratization, liberalization of labour-market, increase of role of management a personnel in a management a railway transport.

A chart over of threats of skilled constituent of economic security of railway transport is brought. In the brought chart over of threats of skilled constituent the external and internal factors of economic security of railway transport are separately considered. Close connection is set between providing of intellectual and skilled constituents of economic security of railway transport, so as events on the increase of their level are sent to work with a personnel. It is set that the system of economic security of railway transport must be formed taking into account modern social changes in society. In detail the basic threats of skilled constituent and reason of their origin are considered on the enterprises of railway transport. Directions that is oriented are educed, on providing of skilled constituent of economic security of railway transport. The list of basic tasks is set for perfection of skilled safety of railway transport, sent to effective administration of personnels.

Вісник економіки транспорту і промисловості № 62, 2018 
Key words: management, economic security of railway transport, skilled constituent, management of operations, organizational structure, a personnel.

Постановка проблеми. Стабільна робота усіх видів транспорту $\epsilon$ невід'ємною умовою функціонування економіки України. Однією з актуальних проблем на сучасному етапі розвитку економіки країни 3 позицій економічної безпеки $\epsilon$ напрямок управління персоналом. Цей напрямок забезпечення економічної безпеки входить до однієї з іiі складових - кадрової складової.

Роль кадрової складової економічної безпеки залізничного транспорту в сучасних умовах постійно зростає. Це обумовлено такими сучасними соціальними змінами в суспільстві, як демократизація, лібералізація економіки й ринку праці, підвищення ролі управління персоналом в управлінні залізничним транспортом. Також спостерігаються процеси ускладнення праці, підвищення ролі творчості й інновацій, надання працівникам волі й автономії в прийнятті рішень, що приводить до ослаблення можливості жорсткого контролю за персоналом [1]. Тому необхідним $\epsilon$ забезпечення окремої кадрової складової економічної безпеки залізничного транспорту різних негативних чинників.

Аналіз публікацій. У науковій літературі за останні роки достатньо повно висвітлено результати досліджень вітчизняних і зарубіжних авторів із різних аспектів проблематики забезпечення кадрової складової економічної безпеки.

Важливий внесок у вивчення проблем теорії та практики кадрової безпеки зробили вітчизняні та зарубіжні вчені, такі як: Бородін I., Геєць В., Іващенко Г., Кібанов О., Швець Н., Чаплигіна Ю. [1], Клепікова А. [2], Лященко О. [3], Назарова Г. [4], Нежданов I., Петров М. [5], Черняк О., Чумарін I. [6], Шаваєв А. [8], Мехеда Н.Г., Маренич А.I. [9], Швець Н. К. [10] та інші.

Названі вчені мають різні підходи до трактування поняття "кадрова безпека", а також мають різні підходи до визначення першочергових завдань по іiі забезпеченню.

Мета дослідження. Встановити вплив сучасних факторів кадрової складової на забезпечення економічної безпеки залізничного транспорту

Викладення основного матеріалу. Кадрова безпека є поняттям складним i багатогранним, i тому сутність кадрової складової полягає в проведенні заходів щодо підвищення кваліфікації працівників, організації системи управління персоналом, підбору кадрів необхідної кваліфікації, ефективного матеріального стимулювання праці працівників, a також їx соціальної захищеності. Вона займає домінуюче положення відносно інших елементів системи економічної безпеки залізничного транспорту, так як вона пов'язана 3 кадрами, а вони в кожній складовій первинні.

Схема загроз кадрової складової економічної безпеки залізничного транспорту подана на рисунку1.

Забезпечення інтелектуальної i кадрової складових економічної безпеки залізниці передбачає два тісно пов'язаних між собою, але водночас й істотно різних напрямків діяльності.

Перший напрямок орієнтований на роботу 3 персоналом, на підвищення ефективності роботи співробітників залізниці, який передбачає роботу 3 планування i управління персоналом залізниці, запобігання загрозам негативних впливів на економічну безпеку залізниці за рахунок недостатньої кваліфікації співробітників залізниці, слабкої організації системи управління персоналом, підбору, навчання і мотивації співробітників залізниці, створення умов для повного виявлення стимулів до високопродуктивної праці з боку кожного робітника, виключення передумов до появи ненадійних співробітників. 


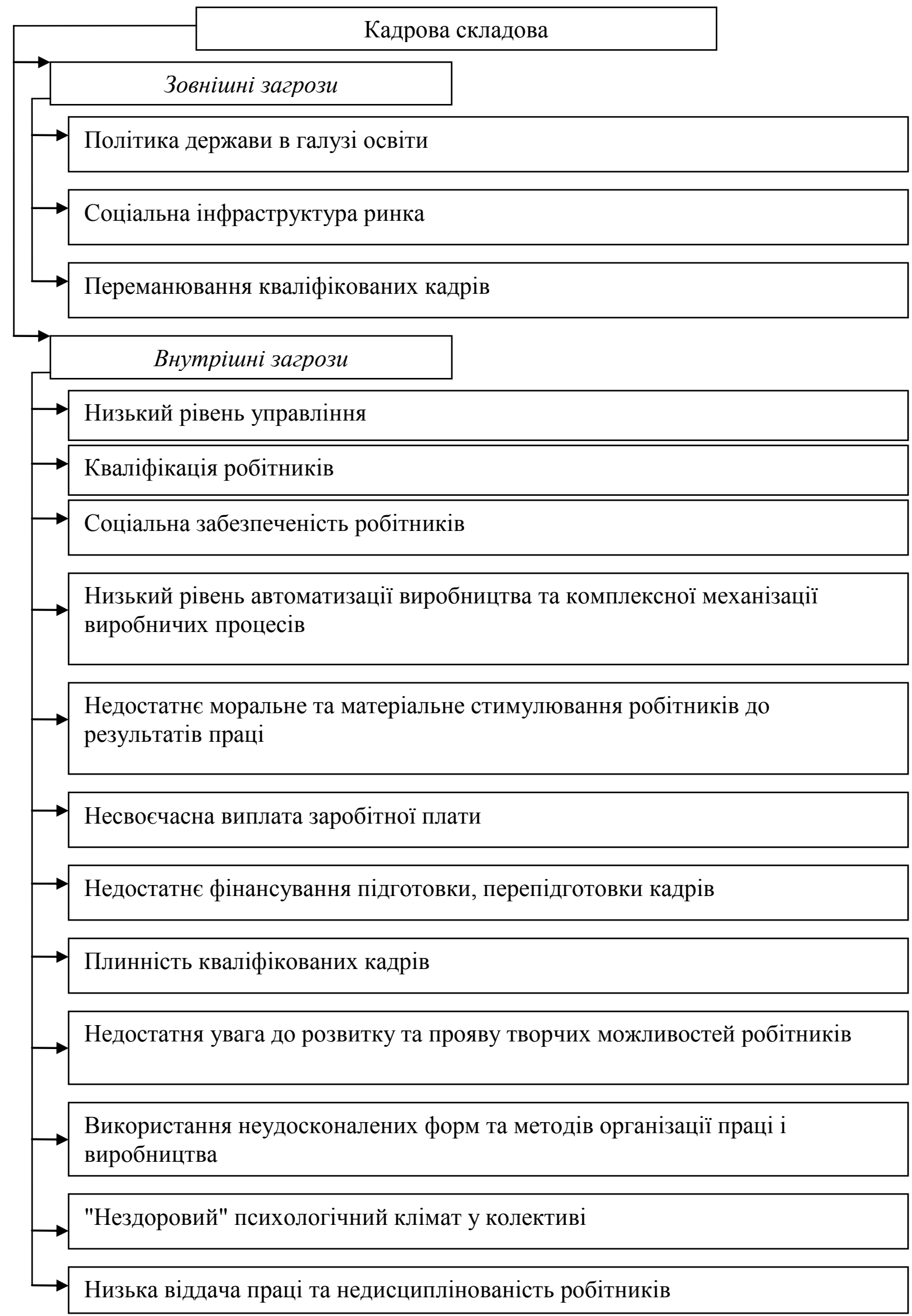

Рис. 1. Схема загроз кадрової складової економічної безпеки залізничного транспорту

Вісник економіки транспорту і промисловості № 62, 2018 
Дуже значної шкоди діяльності підприємств залізничного транспорту завдають якраз ненадійні робітники.

Ненадійність - це деякий динамічний процес, що змінюється в часі під впливом зовнішніх i внутрішніх причин індивіда, що й відображає готовність, почати дії, які в його соціально-культурнім середовищі більш високого рівня можуть бути розцінені, як порушення існуючих норм і традицій. А також і сама поведінка, що порушує ці норми. Неблагонадійний персонал у першу чергу небезпечний схильністю до розголошення службової інформації й комерційної таємниці. Слід звернути увагу на загальносвітову статистику: 10-15 \% всіх людей є нечесними за визначенням, 10-15 \% абсолютно чесні, останні 70-80 \% не визначилися, тобто ті, хто може повестися нечесно.

Другий напрямок спрямований на збереження і розвиток інтелектуального потенціалу залізниці. В економіці, заснованій на знаннях, життєво важливим $\epsilon$ генерація високого людського капіталу, необхідного для стійкого економічного, соціального та культурного розвитку. Інтелектуальний капітал стає основним напрямком процвітання галузі та забезпечення іiї економічної безпеки.

Високий рівень дисципліни; зростання чисельності кваліфікованих кадрів, зниження плинності кадрів, досягнення високого освітнього рівня та компетентність керівників $є$ основними ознаками зниження кадрових ризиків, а отже напрямками, що забезпечують економічну безпеку підприємству. Саме тому, один 3 показників економічної безпеки на сьогоднішній день $є$ рівень освіти персоналу [11].

Ще одним фактором забезпечення економічної безпеки залізничної галузі є інтелектуальний капітал. Він $є$ провідним капіталом і складає основу будь-якого підприємства на сучасному етапі розвитку ринкової економіки.

Головна функція інтелектуального капіталу - істотно прискорювати приріст маси прибутку за рахунок формування i реалізації необхідних галузі систем знань, речей i відносин, які, в свою чергу, забезпечують iii високоефективну господарську діяльність, та як наслідок високий рівень економічної безпеки.

Головною загрозою кадрової складової $\epsilon$ низький рівень управління. 3 належним рівнем управління можна уникнути багатьох загроз не тільки кадрової складової, а й інших складових економічної безпеки залізничного транспорту. Цей факт можна підкреслити словами А.Файоля: "Управляти - означає передбачати, організовувати, розпоряджатися, координувати та контролювати; передбачати, тобто враховувати майбутне i виробляти програму дій; організовувати, тобто будувати подвійний - матеріальний i соціальний - організм підприємства; розпоряджатися, тобто примушувати персонал належно працювати; координувати, тобто зв'язувати, об'єднувати, гармонізувати всі дії, зусилля; контролювати, тобто піклуватися про те, щоб все відбувалося згідно 3 установленими правилами і відданими розпорядженнями" [12].

Незадовільне

управління виробництвом може бути проявом цілої низки загроз, до яких можна віднести: недостатне моральне та матеріальне стимулювання робітників до результатів праці, несвоєчасна виплата заробітної плати, використання неудосконалених форм та методів організації праці i виробництва, "нездоровий" психологічний клімат у колективі.

Але $\epsilon$ ряд факторів, які впливають на стан соціально-психологічного клімату в колективі незалежно від ефективного чи неефективного управління. До таких факторів можна віднести: суспільнополітична ситуація в країні та рівень життя населення.

Цей перелік соціально-економічних загроз позначається на зниженні ефективності праці, і, як наслідок, - 
зниженні рівня економічної безпеки залізничного транспорту.

Значний вплив на рівень економічної безпеки залізничного транспорту має низка загроз, які пов'язані 3 продуктивністю праці:

- безініціативність;

- недостатня кваліфікація

працівників;

- небажання i "лінощі" деяких працівників приносити максимальну користь.

При цьому важливим фактором в викоріненні цих загроз $є$ неефективна система мотивації співробітників галузі. Вивчення і глибоке осмислення проблем трудової мотивації $є$ необхідною умовою здійснення грамотної управлінської діяльності в умовах ринкових відносин. Знання основних економічних i психологічних законів і закономірностей мотиваційного менеджменту, яке дозволить організувати роботу залізничного транспорту таким чином, щоб персонал працював 3 повною самовіддачею й усвідомленою зацікавленістю в досягненні високих кінцевих результатів своєї діяльності.

Персонал мотивований на прояв самостійності, ініціативи; більшою мірою реалізуються потреби людей у повазі, самовираженні, у меншою - почуття захищеності, причетності, тому що працівники змушені самостійно ухвалювати рішення щодо виникаючих проблем.

\section{Соціальна захищеність $\epsilon$} неодмінною умовою розвитку кадрового потенціалу і підвищення продуктивності праці. Але в останній час у зв'язку 3 браком коштів на залізничному транспорті виникають труднощі 3 забезпеченням соціальних потреб, підвищенням матеріального та культурного рівня робітників. Покращення умов праці i техніки безпеки, скорочення використання ручної праці за рахунок підвищення рівня автоматизації та впровадження останніх досягнень науково-технічного прогресу забезпечить більш ефективне використання трудових ресурсів, а також вплине на покращення показників діяльності залізничного транспорту скорочення витрат, зниження собівартості та збільшення прибутку.

В умовах ринкових відносин кінцевий результат виробничоекономічної діяльності стає все більш залежним від внутрішнього ставлення людини до справи, від іiі схильності до праці, від дотримання принципів етики i моралі у відносинах між керівниками i підлеглими. Тому значну роль відіграє психологічний клімат у колективі. Якість і продуктивність праці робітників визначаються не тільки їх економічними інтересами, а й атмосферою відносин в колективі, задоволеністю умовами праці, престижністю професії, можливостями самовираження особи, внутрішніми морально-психологічними установками робітника.

Однією з загроз, яка є постійною для підприємств залізничного транспорту, $\epsilon$ плинність кадрів. Ця загроза тісно пов'язана 3 незадоволеністю робітників умовами праці. Задоволеність працею відображає відповідність виробничих умов на підприємствах залізничного транспорту тим вимогам, які робітники пред'являють до праці, до змістовності та умов праці, заробітної плати і т.п. Незадоволеність працею приводить до втрати кваліфікованих, добре підготовлених фахівців та обумовлених цим втрат.

Велике значення має організаційна структура. Вона повинна відповідати цілям підприємства і засобам їх досягнення. Якість організаційної структури позначається на управлінні. Від управлінського персоналу сьогодні потрібне оперативне ухвалення рішень, які відповідають сучасним вимогам конкурентної боротьби.

Дисципліна $є$ одним 3 основних принципів досягнення загальної мети залізничної галузі, яка включає прояви старанності в роботі, поваги керівників, виконання вимог, прийнятих угод між 
підприємствами і робітниками. Так, Положення про дисципліну працівників залізничного транспорту передбачає, що кожний працівник, на якого поширюється його дія, зобов'язаний дотримуватися правил внутрішнього трудового розпорядку, у відповідності до статуту та положенню про дисципліну [13, 14].

Статути та положення про дисципліну не замінюють правил внутрішнього трудового розпорядку, вони виключають зі сфери дії цих Правил тих працівників, на які поширюються статути, але в межах відносин, що регулюються статутом.

У трудових колективах повинна створюватися обстановка нетерпимості до порушень трудової дисципліни, суворої вимогливості до працівників, які несумлінно виконують свої трудові обов'язки.

\section{Висновки.}

Враховуючи вищесказане, можна виділити основні завдання по вдосконалення кадрової безпеки підприємства:

- створення умов для здорового психологічного клімату в колективі;

$\begin{array}{ccc}\text { - } & \text { підготовка } & \text { нормативної } \\ \text { документації } & \text { для } & \text { співробітників }\end{array}$ організації в інтересах дотримання кадрової безпеки; компаніі;

- формуванні кадрової стратегії

- постійний моніторинг факторів впливу на співробітників галузі, спрямований на забезпечення кадрової безпеки підприємства;

- створення умов соціальної захищеності співробітників галузі;

- створення умов для розвитку персоналу галузі;

- проведення заходів, спрямованих на покращення умов праці та техніки безпеки на підприємствах залізничної галузі;

- проведення роз'яснювальної роботи зі співробітниками організації направленої на забезпечення трудової дисципліни у колективах.

\section{СПИСОК ВИКОРИСТАНИХ ДЖЕРЕЛ}

1. Чаплигіна Ю.С. Етимологічний аналіз категорії «кадрова безпека» / Ю.С.Чаплигіна // Управління розвитком. 2011. - № 4 (101). - c. 102-104.

2. Клепикова А., Нежданов И. Служба персонала и служба безопасности должны работать в команде // Управление персоналом. - 2001. - №3. - С. 36.

3. Лащенко О. Ю. Кадрова безпека як підсистема в системі економічної безпеки підприємства. - Суми: Видавництво «Довкілля», 2003. - 326 с.

4. Назарова Г. В. Формування та розвиток людського капіталу корпоративного підпри- ємства Наукове видання / Н. Л. Гавкалова, Н. С. Маркова, Г. В. Назарова. - Харків: Вид. ХНЕУ, 2006. $-238 \mathrm{c}$.

5. Петров М. I., Економічна безпека підприємства: сутність, трактування, точки зору» // Менеджер. - 2002. - № 1(17). $-67-71 \mathrm{c}$.

6. Чумарин И. Г. Что такое кадровая безопасность компании? // Кадры предприятия. - №2. - 2003. - С. 25 29.

7. Чумарин И. Г. Функции и задачи службы персонала в области обеспечения экономической безопасности // Кадры предприятия. - № 3(03). - 2003. - С. 31.

8. Шаваев А. Г. Безопасность корпораций. Криминологические, уголовно-правовые и организационные проблемы. - М.: «Банковский Деловой Центр», 2007. - 239 с.

9. Мехеда Н.Г., Маренич А.I. Соціально-мотиваційні складові кадрової безпеки // Фінансовий простір: міжнародний науково-практичний журнал / Черкаський інститут банківської справи Університету банківської справи НБУ (м. Київ). - м. Черкаси. - №2 (6) 2012. - С. 3845.

10. Швець Н. К. Методи виявлення i збереження кадрової безпеки, або як перемогти зловживання персоналу/ Н. К. Швець // Персонал. -2006. - № 5. - С. 31- 


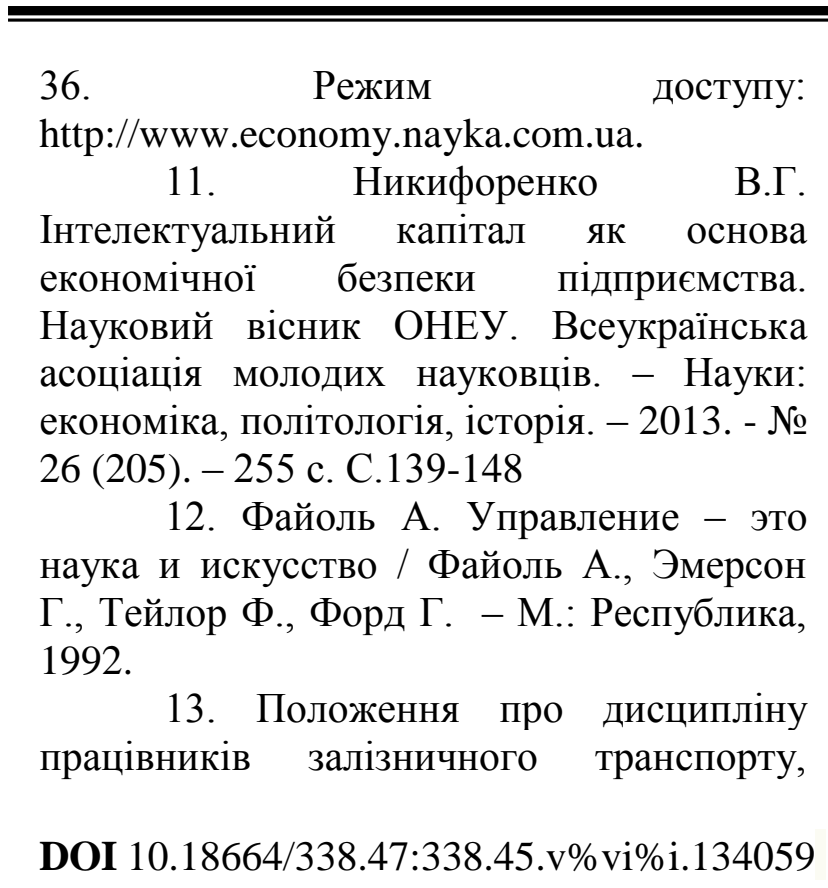

затверджене постановою Кабінету Міністрів України від 26.01.1993 р. № 55.

11. Никифоренко В.Г. 14. Статут про дисципліну працівників зв'язку, затверджений постановою Кабінету Міністрів України від 30 липня 1996 р. № 877.

15. Формирование социальнопсихологического климата коллектива [електронний ресурс] - Режим доступа: http://medicina.dlyakajdogo. ru/index. $\mathrm{php} / \mathrm{mnu}$-glavnoe/psihologia/262-

formirovanie-sotsialnopsikhologicheskogo klimata-kollektiva

\title{
УДК 65.01:656.2
}

\section{ВПРОВАДЖЕННЯ ЦІННІСНО-ОРІЄНТОВАНОГО УПРАВЛІННЯ НА ЗАЛІЗНИЧНОМУ ТРАНСПОРТІ}

\author{
Токмакова I.В., д.е.н, професор, \\ Войтов І.М., ст. викладач, \\ Носенко Л.М., магістр (УкрДУЗТ)
}

\begin{abstract}
В статті досліджено сутність ціннісно-орієнтованого управління та визначено, щзо його переваги полягають у орієнтації аналітичних технік та управлінських процесів підприємств на максимізаџію їх ијіноості шляхом фокусування прийняття управлінських рішень на ключових факторах (драйверах) створення иінності. Розкрито послідовність впровадження ціннісно-орієнтованого управління на підприємствах залізничного транспорту, що включає такі етапи: стратегічне планування (визначення місії та ієрархії цілей), визначення функціональних иілей, тобто побудова стратегічної карти, визначення критичних факторів успіху, визначення ключових індикаторів ефективності, формування збалансованої системи показників, ї автоматизація та впровадження. Проаналізовано основні підходи до оцінки вартості бізнесу (дохідний (прибутковий), порівняльний (ринковий) і витратний (майновий)) та зроблено висновки щэодо їх застосування на підприємствах залізничного транспорту.
\end{abstract}

Ключові слова: управління, цінність, оцінка вартості, збалансована система показників, залізничний транспорт.

(C) Токмакова I.B.,

Войтов I.M., Носенко Л.М. 